\title{
Japan's Development Cooperation for Health in Vietnam: a First Holistic Assessment on Japan's ODA and Non-ODA Public Resources Cooperation
}

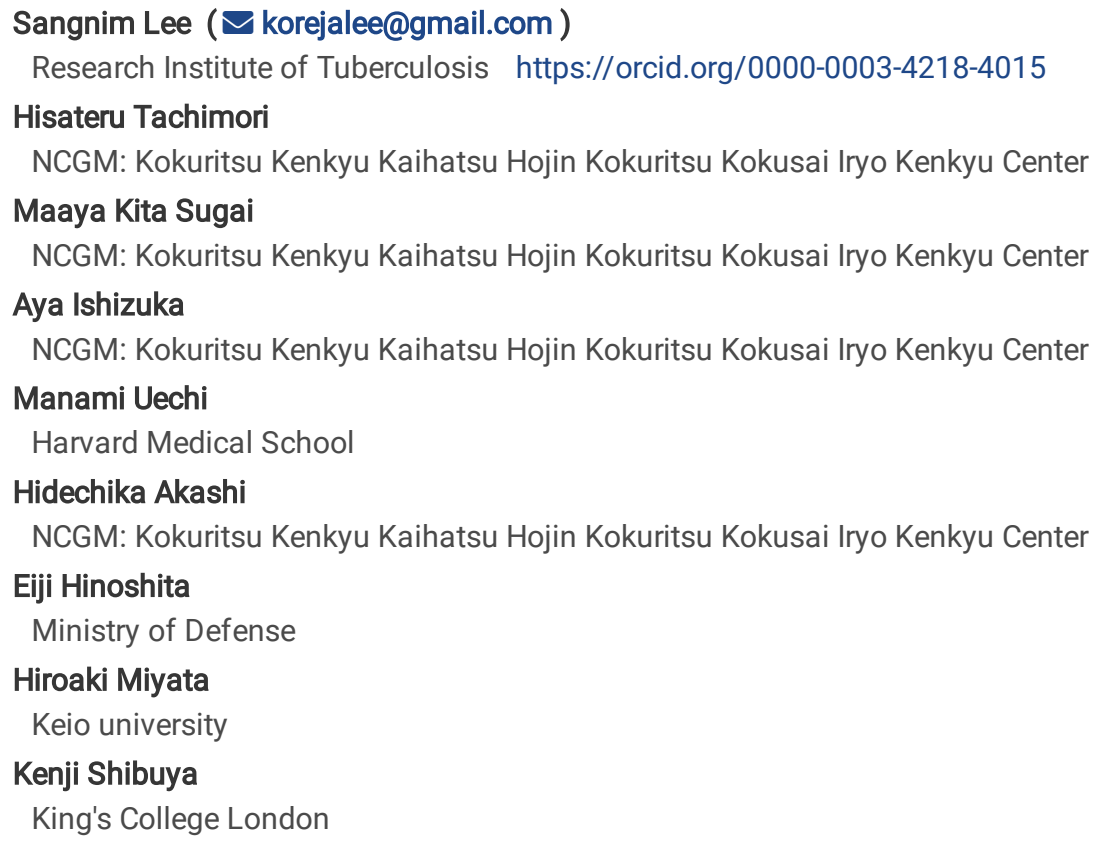

Research article

Keywords: Japan, ODA, health policy, Vietnam, UHC, Health system strengthening, health systems, development cooperation, health, SDGs

Posted Date: February 15th, 2021

DOI: https://doi.org/10.21203/rs.3.rs-234703/v1

License: @ (i) This work is licensed under a Creative Commons Attribution 4.0 International License. Read Full License 


\section{Abstract}

Background

To achieve Universal Health Coverage (UHC), which is the core driver of health Sustainable Development Goals (SDGs), by 2030, Japan strives to strengthen its development cooperation by mobilizing various resources. However, the involvement and roles of various actors from Japan in development cooperation for health have not been revealed across various entities of the Japanese government or to the public. This study is the first to systematically assess the overall picture of Japan's publicly funded cooperation mobilizing Official Development Assistance (ODA) and non-ODA public resources to improve people's health in Vietnam.

Methods

A cross-sectional analysis of Japanese publicly funded projects implemented for health cooperation in Vietnam during December 2016 was conducted. A framework based on the six building blocks of health system defined by the World Health Organization was adopted in order to assess the target projects.

Results

Overall, 68 projects implemented through Japanese public funding were included in the final analysis. These 68 projects under 15 types of schemes were managed by seven different scheme-operating organizations and funded by five ministries. Forty-four of these (64.7\%) were ODA and 24 (35.3\%) were non-ODA projects. Among the recategorized six building blocks of the health system, the focus area of the largest proportion of projects was health service delivery $(44 \%)$, followed by health workforces $(25 \%)$ and health information systems $(15 \%)$. Almost half the projects were implemented together with the central hospitals as Vietnamese counterparts. Only $10 \%$ projects were conducted at the local level. This study was unable to capture the synergetic effects of potential collaboration or harmonization among Japanese funded projects.

Conclusions

Several Japanese-funded projects addressed a wide range of health issues across all six building blocks of the health system in Vietnam. However, there is room for improvement in developing coordination and harmonization among the Japanese projects that are diversifying. Furthermore, establishing a target-country-specific mechanism for strategic coordination across Japanese ministries' schemes can yield efficient and effective development cooperation for health. Our analytic approach using the recategorized six building blocks contributes to a more comprehensive understanding of efforts on strengthening the health system.

\section{Background}

Universal health coverage $(\mathrm{UHC})$ of quality and affordable essential health services for all is the core driver of health sustainable development goals (SDGs)[1]. For the world to achieve UHC by 2030, various resources need to be mobilized at the national and global levels[1, 2]. Japan was the fourth largest donor of disbursements in Official Development Assistance (ODA) in 2019[3]. Japan's ODA policy, called the Development Cooperation Charter, was adopted in 2015 [4]. It emphasizes the promotion of development cooperation by not only mobilizing ODA, but also by collaborating with other funding resources and activities of the government, and various entities such as private sector corporations and civil society organizations. The charter aims to achieve peace, stability, and prosperity of the international community, which, it explains, will also be beneficial to Japan. In addition, a health sector specific policy of the Charter called "the Basic Design for Peace and Health" was approved by the Headquarters for Healthcare Policy headed by the prime minister and adopted in the same year[5]. This policy highlights the importance of strengthening the health system in order to achieve UHC, and illustrates the government's plan to promote development cooperation for health by mobilizing Japan's expertise, experience, technology, and medical products through the utilization of various public resources[5].

These ODA policies align with Japan's domestic health policies as well. In 2014, the government formulated the Healthcare Policy under the newly passed Act to Promote Healthcare and Medical Strategy[6], which aims to promote health and longevity in Japan as well as abroad. The Act is grounded on the idea of mutual growth and seeks to facilitate the overseas expansion of Japan's medical products, technologies, and services.

The development of the ODA and domestic health policies has promoted both development cooperation for health as well as the overseas expansion of the Japanese health sector. As a result, Japan's development cooperation for health in recipient countries has been implemented by not only ODA-related agencies, but also by other entities such as the Ministry of Health, Labour and Welfare (MHLW), the Ministry of Economy, Trade and Industry (METI), private sector corporations, and other entities [7]. Although the Headquarters for Healthcare Policy urges 
the ministries to coordinate with one another under the "the Basic Design for Peace and Health," the overall picture of health cooperation implemented on the ground has not been clearly mapped or understood.

To assess Japanese development cooperation for health, we decided to study the case of Vietnam, which ranked third by recipient country in Japan's gross bilateral ODA in 2018[3], and where Japan is the largest donor [8]. This research is the first attempt to systematically assess the overall picture of Japan's publicly funded cooperation by both ODA funds and other non-ODA public funds to improve health in another country, in this case Vietnam. We also assessed Japan's health cooperation efforts by a health system framework to review how Japanese cooperation is contributing to the attainment of UHC [1] in Vietnam. The results of this study are expected to contribute to the ongoing and future discussions on effective recipient country specific cooperation strategies for the health sector.

\section{li. Methods}

Scope of analysis and data collection

A cross-sectional analysis of Japanese publicly funded projects (including both ODA and non-ODA expenses) related to cooperation for health in Vietnam was conducted. The analysis included health-related projects that were implemented in Vietnam during the month of December 2016. Projects in the fields of long-term care and social security were also included in the scope of analysis as these areas are closely related to health. An internet search to identify the projects was conducted between July and September 2017; the details of this search are presented in an additional table file (see Additional file 1). The projects' eligibility for the study was assessed by reviewing the project titles, basic information, and summary of projects. Projects that could not be confirmed to be publicly funded and projects that were a part of a larger research project were excluded. The remaining projects were further screened by assessing additional information on project publications. During this screening process, the projects whose primary purpose did not serve to improve the health system of Vietnam and projects whose counterparts had not been disclosed were excluded. The selection process of the target projects is summarized in Fig. 1 . The basic information of the target projects (details in Additional file 1) was collected and assessed. Wherever needed, additional information was collected face-toface, via phone, or via e-mail from the relevant organizations responsible for the projects included in this study.

Framework of analysis

In this research, a framework based on the six building blocks of the World Health Organization's (WHO) health system [9, 10] was adopted to conduct the analysis. As shown in Table 1, the six building blocks describe the core components of a health system, and have been adopted for assessments of global health initiatives and the health system at the country system level in previous researches [11-14]. In order to classify the projects identified in our study, the six building blocks were broken down into the three tiers of "building blocks," "function," and "activities component" based on past literature and expert consultation [15-18]. 
Table 1

Activities Categorized by WHO's Six Building Blocks of Health Systems

\begin{tabular}{|c|c|c|}
\hline Building Block & Function & Activity Component \\
\hline \multirow[t]{11}{*}{ Health service delivery } & \multirow[t]{3}{*}{ Service availability } & Infrastructure (Facility (number and distribution)) \\
\hline & & Health workforce availability \\
\hline & & Service utilization (inpatient and outpatient visits) \\
\hline & \multirow{7}{*}{$\begin{array}{l}\text { General and specific service } \\
\text { readiness }\end{array}$} & Infrastructure/ amenities \\
\hline & & Supply/ equipment \\
\hline & & Standard precautions \\
\hline & & Laboratory tests (diagnostics) \\
\hline & & Medicines and commodities \\
\hline & & Staff and training (service standardization, program specific) \\
\hline & & $\begin{array}{l}\text { Diagnostic skills and training (capacity standardization, program } \\
\text { specific) }\end{array}$ \\
\hline & Service quality & $\begin{array}{l}\text { Service improvement (coverage, effectiveness, safety, patient- } \\
\text { centeredness, timeliness) }\end{array}$ \\
\hline \multirow[t]{6}{*}{ Health workforce } & \multirow{6}{*}{$\begin{array}{l}\text { Training, recruitment and } \\
\text { retainment }\end{array}$} & Human resources (HR) development plan \\
\hline & & Training \\
\hline & & HR performance and management \\
\hline & & Education \\
\hline & & Regulations (licensing and accreditation) \\
\hline & & HR production, recruitment and data management \\
\hline \multirow{11}{*}{$\begin{array}{l}\text { Health information } \\
\text { systems }\end{array}$} & \multirow{7}{*}{$\begin{array}{l}\text { Generation of population and } \\
\text { facility based data }\end{array}$} & Health survey \\
\hline & & Census \\
\hline & & Civil registration \\
\hline & & Disease management information system \\
\hline & & Health facility reporting \\
\hline & & Public health surveillance system \\
\hline & & Health system resource tracking \\
\hline & \multirow{4}{*}{$\begin{array}{l}\text { capacity for analysis, synthesis and } \\
\text { validation of data }\end{array}$} & Public health threat response system \\
\hline & & Performance tracking \\
\hline & & Monitoring and research \\
\hline & & Country, regional and global data analysis \\
\hline \multirow[t]{7}{*}{$\begin{array}{l}\text { Medical products, } \\
\text { vaccines and } \\
\text { technologies }\end{array}$} & \multirow{7}{*}{$\begin{array}{l}\text { Access to essential medical } \\
\text { products, vaccines and } \\
\text { technologies }\end{array}$} & $\begin{array}{l}\text { Policy development (national policies, standards, guidelines and } \\
\text { regulations) for essential medicines, vaccines and technology }\end{array}$ \\
\hline & & Procurement of essential medicines and vaccines \\
\hline & & Quality assessment of priority products \\
\hline & & $\begin{array}{l}\text { Support for rational use of essential medicines, commodities and } \\
\text { equipment }\end{array}$ \\
\hline & & $\begin{array}{l}\text { Technological assessments (stimulate development, testing and use of } \\
\text { new products, tools, standards and policy guidelines) }\end{array}$ \\
\hline & & Insurance coverage (\% population covered, price and cost of medicine) \\
\hline & & Essential medicines (14 medicines) \\
\hline
\end{tabular}




\begin{tabular}{|c|c|c|}
\hline Building Block & Function & Activity Component \\
\hline \multirow[t]{3}{*}{ Health system financing } & \multirow[t]{3}{*}{ Financing } & Collection of revenues (domestic and international funding sources) \\
\hline & & Risk pooling (benefit coverage and entitlement) \\
\hline & & Purchasing of services \\
\hline \multirow[t]{3}{*}{$\begin{array}{l}\text { Leadership and } \\
\text { Governance }\end{array}$} & \multirow[t]{3}{*}{ Policy, Leadership, Governance } & $\begin{array}{l}\text { National policy and strategies, action plans (including disease/program } \\
\text { specific ones) }\end{array}$ \\
\hline & & Accountability \\
\hline & & Working with external partners \\
\hline
\end{tabular}

We deferred to definitions from the WHO reference materials to determine the categorization of activities that can span across two building blocks $[10,16]$. For example, we identified pre-service and in-service training as a part of the "health workforce" building block if the activity resulted in newly qualified health professionals or cadres, and as a part of the "health service delivery" building block if the activity was identified as quality improvement and service enhancing training for health professionals.

The projects were further "recategorized" as a separate variable to account for multiple building blocks a project may be covering. For instance, projects labeled "health service delivery" as their primary categorization were labeled with an additional categorization of "health workforce" if the projects addressed this component as well.

In order to measure project outcomes contributing to the development of the Vietnamese health sector, two types of indicators, outcome and output, were assessed. Outcome indicators are "changes brought about to targets by means of intervention output by projects" and output indicators are "outputs, capital goods, and services generated as a result of assistance or changes brought about by assistance" [19-21].

Project classification and data analysis

The targets, outcomes, and indicators of each project were carefully reviewed to classify the projects based on the analysis framework of the six building blocks adopted for this study. Each project's counterpart organizations in Vietnam were identified based on the documents reviewed. These organizations were classified as one of the following types of institutions: governmental administrative bodies, public medical facilities, research institutions, educational institutions, and others such as non-governmental organizations and private hospitals. In Vietnam, there are four levels of health administration for healthcare services and management: central, provincial, district, and commune [22]. In this study, the level of health administration for the counterpart organizations of governmental administrative bodies and public medical facilities was classified into the three levels of central, provincial, and local. Tertiary level hospitals, categorized as Level 1 hospitals in Vietnamese health administration, were classified as the central level of health administration in this study [23]. The local level of health administration included city, district, and commune levels. The commune people's committees were categorized under the local level because of the role of such committees in the official management of the health system. If a project did not fit into any of these categories, it was classified as "others."

Coding was implemented by two researchers independently (SL, MU). Each project was analyzed based on the framework adopted for this research. When the two researchers had different opinions on the classification, a discussion was held to reach a consensus, whose outcome would then be adopted. When the classification criteria were unclear, the research members (SL, MU, Al) discussed further to segment and review the criteria. Some projects showed indications of being implemented at several health administration levels simultaneously. In such cases, the number of projects and financial contribution by level were weighted proportionately to the number of levels (multiplying $1 / n$ to the financial contribution when there are $n$ levels and redistributing equally to each level). Data on the six building blocks identified the main block, which was directly used to identify the "main six building blocks." Meanwhile, as some projects were categorized under several building blocks, the same adjustment procedure was taken to proportionately weight the number of building blocks, in order to correspond to the complex reality of health projects.

First, the annual budget for each project was estimated using the total project cost per year and converted to USD ( $1 \$=108.79 ¥)$ based on the Organisation for Economic Co-operation and Development exchange rate as of 2016. A frequency distribution of the number of projects was created, and financial contributions by each of the main six building blocks as well as their proportion out of the total contribution of projects assessed in this study were estimated. Second, the aggregated financial contributions and their proportion out of the total were described by the building blocks and the level of health administration. Last, visualization flowcharts were created to track resource allocation by scheme operating organization, health administration level, main six building blocks, and recategorized six building blocks.

Preliminary results were shared with the relevant ministries and agencies and ODA implementation organizations to assess data accuracy and improve the data contents. In each case, the comments and information obtained were recorded in research notebooks and the project classification was revised as needed based on the feedback received. 


\section{lii. Results}

A total of 81 projects were retrieved through the internet search, and 68 projects were deemed to be eligible for inclusion in the final analysis. These 68 projects under 15 types of schemes were managed by 7 different scheme-operating organizations and funded by 5 ministries (see Table 2). Of these, 44 (64.7\%) were ODA projects funded by the Ministry of Foreign Affairs, whose schemes were operated by the Japan International Cooperation Agency (JICA) (37 projects), Embassy of Japan in Vietnam (six projects), and jointly by JICA and Japan Agency for Medical Research and Development (AMED) (one project). The remaining 24 projects (35.3\%) were non-ODA projects funded by the MHLW; METI; Cabinet office; and Ministry of Education, Culture, Sports, Science and Technology. These projects' schemes were operated by the MHLW (11 projects), National Center for Global Health and Medicine (six projects), AMED (four projects), METI (two projects), and Japan External Trade Organization (one project). The Japanese organizations that implemented these projects were central and local governments, public agencies, ODA implementation agency, medical institutions, medical associations, research institutions, educational institutions, private sector companies, and non-governmental organizations. Their major counterparts in Vietnam were governmental health administration and public medical facilities. The median project implementation period was 24.7 months, ranging from 5 months to 5 years.

Table 2

Project funding agencies and their schemes, 2016

\begin{tabular}{|c|c|c|c|c|c|c|}
\hline \multirow[t]{2}{*}{$\begin{array}{l}\text { Funding } \\
\text { Ministry }\end{array}$} & \multirow{2}{*}{$\begin{array}{l}\text { Scheme } \\
\text { Operating } \\
\text { Organization }\end{array}$} & \multicolumn{2}{|c|}{$\begin{array}{l}\text { Identified } \\
\text { Projects }\end{array}$} & \multicolumn{2}{|l|}{ Schemes } & \multirow[t]{2}{*}{ ODA } \\
\hline & & (n) & $(\%)$ & Scheme name & (n) & \\
\hline \multirow[t]{7}{*}{ MOFA } & \multirow[t]{5}{*}{ JICA } & \multirow[t]{5}{*}{37} & \multirow[t]{5}{*}{54.4} & Loan Aid & 5 & ○ \\
\hline & & & & Technical Cooperation Projects & 4 & 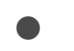 \\
\hline & & & & JICA Partnership Projects & 6 & 0 \\
\hline & & & & Japan Overseas Cooperation Volunteers & 17 & ○ \\
\hline & & & & Public-Private Partnership & 5 & ○ \\
\hline & JICA/AMED & 1 & 1.5 & $\begin{array}{l}\text { Science and Technology Research Partner-ship for Sustainable Development } \\
\text { (SATREPS) }\end{array}$ & 1 & ○ \\
\hline & $\begin{array}{l}\text { Embassy of } \\
\text { Japan in } \\
\text { Vietnam }\end{array}$ & 6 & 8.8 & Grant Assistance for Grassroots Human Security Projects & 6 & ○ \\
\hline \multirow[t]{2}{*}{ MHLW } & MHLW & 11 & 16.2 & $\begin{array}{l}\text { The International Promotion of Japan's Healthcare Technologies and } \\
\text { Services }\end{array}$ & 11 & \\
\hline & NCGM & 6 & 8.8 & Operational Funds & 6 & \\
\hline \multirow[t]{3}{*}{ METI } & \multirow[t]{2}{*}{ METI } & \multirow[t]{2}{*}{2} & \multirow[t]{2}{*}{2.9} & $\begin{array}{l}\text { Program to Promote Medical Technologies and Services (Iryo Gijyutsu } \\
\text { Sabisu Kyotenka Sokushin Jigyou) }\end{array}$ & 1 & \\
\hline & & & & $\begin{array}{l}\text { Survey Programs for Promotion of High Quality Infrastructure System } \\
\text { Development in Overseas (Shitsu no Takai Infura Shisutemu Kaigai Tenkai } \\
\text { Sokushi Chosa-to Jigyo) }\end{array}$ & 1 & \\
\hline & JETRO & 1 & 1.5 & Survey Projects (Chosa Jigyou) & 1 & \\
\hline $\begin{array}{l}\text { Cabinet } \\
\text { office }\end{array}$ & AMED & 4 & 5.9 & $\begin{array}{l}\text { Japan Initiative for Global Research Network on Infectious Diseases (J- } \\
\text { GRID) }\end{array}$ & 1 & \\
\hline /METI/MEXT & & & & Research Program on the Challenges of Global Health Issues & 2 & \\
\hline /MHLW & & & & Research Program on Emerging and Re-emerging Infectious Diseases & 1 & \\
\hline Total & & 68 & & & 68 & \\
\hline
\end{tabular}

Figure 2 shows the flow in proportion to the number of projects by scheme operating organizations, health administration level, and purposes categorized into the main and recategorized building blocks. Most projects were operated either at the central level (44\%) or at the provincial level (34\%). About $60 \%$ of the projects implemented at the central level were non-ODA projects, while the rest were ODA projects. ODA projects constituted $71 \%$ of the total projects implemented at the provincial level, while the rest were non-ODA projects. ODA projects constituted $80 \%$ of the total projects implemented at the local level, with the rest being non-ODA projects. Among the main six building blocks, the largest number of projects was concentrated in the area of health service delivery (63\%), followed by health information systems (19\%). Among the recategorized six building blocks, the focus area of the largest number of projects was health service delivery (44\%). This was followed by the 
focus areas of health workforces (25\%); health information systems (15\%); medical products, vaccines, and technologies (13\%); health system financing (2\%); and leadership and governance (2\%).

Almost half of the projects focusing on health service delivery as the main building block identified central hospitals as their counterparts. Among these, 15 projects, in particular, were carried out with two specific central hospitals. The projects for this building block focused on infrastructure development and the technical improvement of medical services. For example, some projects operated by JICA and MHLW strove to improve inter-professional work relating to the quality of medical services and patient safety in order to enhance overall hospital management. Other projects in this building block category sought to enhance medical services relating to rehabilitation, stroke, and diabetes mellitus. In particular, under the JICA's Japan Overseas Cooperation Volunteers scheme, 17 projects dispatched healthcare personnel such as occupational therapists and physical therapists, and other personnel providing care and support for disabled children to health facilities, mainly at the provincial level. Two-third of the projects for health service delivery incorporated health workforce activity in order to improve the quality of health services. This trend has led to an increase in the proportion of projects focusing on the health workforce in the recategorized building block.

With regard to the building block of health information systems, a majority of projects that were non-ODA projects were collaborative health researches between Japanese and Vietnamese research institutions. AMED projects advanced research on various infectious diseases, which contributed to the improvement of knowledge on the diagnosis, prevention, and treatment of infectious diseases between Japanese universities and Vietnam's national health institutes working on infectious diseases. The National Center for Global Health and Medicine implemented mostly clinical researches with a central hospital. Under the METI's scheme, the Japanese private sector collaborated with a Vietnamese central hospital to launch a project operating medical services and radiological examinations efficiently by utilizing Japanese healthcare information and communication technology.

Several projects contributed toward medical products, vaccines, and technologies by providing medical equipment for health facilities and promoting Japanese health technologies. An example of this includes JICA's project that aimed to enhance the local production capacity of a combined measles and rubella vaccine in Vietnam.

Project budget

According to information disclosed by 39 projects on their project budget, a total of 9.3 billion $¥$ (US\$ 85.4 million) was invested for health cooperation in Vietnam in 2016 (Table 3). The median project budget was 10.0 million $¥$ (US\$ 91,918) in 2016, ranging from 4.0 million $¥$ (US\$ $36,967)$ to 5.7 billion $¥$ (US\$ 52.6 million).

Table 3

Annual budget proportion by six building blocks, 2016

\begin{tabular}{|llllll|}
\hline Six Building Blocks & \multicolumn{2}{c}{ Total Projects } & \multicolumn{2}{c|}{ Projects with budget information } \\
\cline { 2 - 6 } & $\mathbf{n}$ & $\%$ & $\mathbf{n}$ & USD (mil) & $\%$ \\
\hline Health Service Delivery & 43 & 63.2 & 26 & 62.3 & 73 \\
\hline Health Workforce & 4 & 5.9 & 4 & 1.4 & 1.7 \\
\hline Health Information System & 13 & 19.1 & 2 & 0.9 & 1.1 \\
\hline Medical Products, Vaccines and Technologies & 5 & 7.4 & 4 & 16.4 & 19.2 \\
\hline Health System Financing & 1 & 1.5 & 1 & 3.5 & 4.1 \\
\hline Leadership and Governance & 2 & 2.9 & 2 & 0.8 & 1 \\
\hline Total & 68 & 100 & 39 & 85.4 & 100 \\
\hline 1 \$=108.79 $¥$ (Organisation for Economic Co-operation and Development exchange rate, 2016)
\end{tabular}

Figure 3 shows the flow of the annual project budgets, by scheme operating organizations and their scheme types, health administration level, and purposes categorized into the main building blocks and recategorized building blocks. By scheme type, the largest project budget was of JICA's loan aid scheme (88\%) followed by JICA's technical cooperation scheme (7\%). The majority of the project budget was distributed to the central level of Vietnam's health system (75\%), followed by the provincial level (21\%) and the local level (1\%). This is mainly due to the largest investment being utilized in the construction of a new central hospital by JICA's loan aid; this project aimed to alleviate overcrowding of patients in the current largest central hospital in a specific region of Vietnam. On assessing project budget based on the six building blocks, most of the budget was found to be concentrated in the area of health service delivery (73\%), followed by medical products, vaccines, and technologies (19\%). When recategorized, the budget mainly dispersed among health service delivery (35\%), medical products, vaccines, and technologies

Page 7/17 
(34\%), and health information systems (26\%). The proportion of annual project budget categorized by the WHO's six building blocks and level of health administration is shown in Additional file 2.

Project outcome indicators

Figure 4 illustrates the assessment of the outcome indicators of the projects. Among the 45 projects that did not have a publicly available final report in September 2017, 32 projects were still under implementation, while the remaining 13 projects had been completed within a six-month period prior to September 2017. Mid-term or final reports were publicly available for only 23 projects, out of which four were survey projects and were excluded from further assessment. This is because these surveys were conducted for assessing the situation and needs relating to the target topic for formulation of future projects; thus, their project outcome did not satisfy our indicator, "changes brought about to targets." Out of the 19 projects with confirmed project outcomes, 11 projects $(57.9 \%)$ published evaluation reports with output indicators and 5 projects $(26.3 \%)$ published reports with outcome indicators. The remaining three project reports (15.8\%) described subjective impressions and reflections without an outcome- or output-based objective indicator.

\section{Iv. Discussion}

Overall picture of Japan's development cooperation for health in Vietnam

To our knowledge, this is the first study that identified an overall picture of Japanese development cooperation for health in Vietnam for both ODA and non-ODA public funded projects. This is also the first study to assess Japanese health cooperation using the WHO's framework of six building blocks. A total of 68 projects were funded by the Ministry of Foreign Affairs and four other ministries; and implemented by a wide range of entities including governmental agencies, medical institutions, academia, for-profit businesses, and civil society organizations. These entities mobilized their technical expertise, with a heavy focus on heath service delivery, in cooperation with Vietnamese counterparts from central, provincial, and local levels. This involvement of diverse resources supported the aim of Japanese polices that have endeavored to utilize Japan's non-ODA public financial resources and various other resources in development cooperation [4].

The projects in our study sample addressed a wide range of health issues across all six building blocks of the Vietnamese health system. In the categorical analysis of the main six building blocks, health service delivery accounted for the focus of more than $60 \%$ of the projects, followed by health information system. This trend is similar to a previous study that reported service delivery and health information systems to be the most common interventions in five African countries [24]. In contrast, the recategorized building blocks showed a clear change in terms of the increased proportions of the other building blocks. This reveals that the target of Japanese funded projects was not necessarily concentrated in the area of health service delivery block. Through the recategorization, it became clear that one-quarter of the projects were devoted to health workforce. Similar to our research results, health service delivery and health workforce were included among the three major approaches to strengthen the health system of eight countries including Vietnam in a study analyzing Germany's bilateral cooperation with these eight countries [25]; however, the funding resources of this study included only ODA. Unlike Germany, whose most prioritized focus area was leadership and governance, only three ODA projects in our study focused on leadership and governance as well as health financing. These blocks play a significant function in advancing UHC [26]. Since leadership and responsible stewardship are essential in directing an efficient health system at a national level[27], further cooperation in this area should be fostered.

Strong cooperation with the central hospitals

This study observed health cooperation with the central hospitals to be a major characteristic of Japan's development cooperation for health in Vietnam. Almost half of the projects involved Vietnam's central hospitals; specifically, two central hospitals in large cities were involved in 25 projects. The budget distribution was also the largest at the central level.

The concentration of projects in central hospitals can be considered a result of the historical background of Japan's ODA with Vietnam. After resuming Japan's ODA in 1992, JICA implemented various projects targeting central hospitals that served as regional medical service hubs in the northern, central, and southern regions of Vietnam. Several projects were conducted by both the grant aid scheme for infrastructure development of hospitals and the technical cooperation scheme for improving the quality of medical services and hospital management, and developing human resources [28]. It is likely that the long-term partnership of Japan with these central hospitals through ODA resulted in their being considered as co-implementing institutions when starting a new project. Accordingly, various projects have been launched with these central hospitals by utilizing ODA schemes such as the public-private partnership (PPP) scheme of JICA as well as the relatively new non-ODA schemes of MHLW and METI for promoting Japan's medical skills and technology internationally. Clinical research projects have also been launched as a new area of collaboration between Japanese institutes and Vietnamese central hospitals using MHLW funds.

The close cooperation with these central hospitals can be utilized by Japanese funded projects to proceed to the next stage of cooperation, aimed at addressing the major challenges in health service delivery in Vietnam. A plan of Vietnamese Ministry of Health for people's health 
protection, care, and promotion between 2016 and 2020 aimed to reduce the overcrowding of patients, particularly at the central hospitals, which has been a long-term challenge in Vietnam[29, 30]. Several measures were proposed in this five-year plan, such as increasing the number of health facilities at all levels, developing a satellite hospital network, and enhancing technical transfer between medical institutions across health administration levels by rotating human resources for health. However, this study found that only a few Japanese funded projects worked to improve medical services at provincial or local levels by linking the central and provincial level health systems. For example, an MHLW project collaborated with a Vietnamese central hospital and a medical educational institute for implementation of Vietnam's policy on the ground by strengthening a rotation training system for newly graduated physicians working at provincial hospitals. Additionally, a JICA project that aligned with Vietnam's health policy, called the "Direction Office for Healthcare Activities (DOHA)," worked to strengthen the referral system between medical facilities at different health administration levels in mountainous areas, and promoted clinical skill guidance and supervision activities among these medical facilities[23].

Since the Japanese funded projects majorly concentrate on the central hospitals, a greater number of projects funded by Japan should leverage the strengths of this cooperation with the central hospitals. Doing so will allow the central hospitals to efficiently and simultaneously transfer advanced and cutting-edge technical skills to provincial level health facilities. For example, Vietnam's Satellite Hospital Project prioritized several specialties such as oncology, traumatology, and cardiology, and has actively promoted the transfer of its advanced medical and surgical skills from the central to provincial hospitals [23]. Carrying out projects that align with core Vietnamese priorities and policies jointly with central hospitals could further enhance Vietnam's sense of ownership and contribute toward a sustainable health system. These efforts would allow more patients to receive quality medical and healthcare services locally, which, in turn, would reduce the workload of central hospitals.

Addressing health disparity by improving Primary Health Care through further cooperation

In order to reduce heath disparities between the urban and rural populations, effective provision of appropriate healthcare services at the community level in the rural areas of Vietnam is a key challenge [29, 31]. Major efforts have been made by the Vietnamese Ministry of Health's initiatives to improve Primary Health Care (PHC) such that healthcare services are accessible to all people who need it [32, 33]. Quality and accessible primary healthcare is essential for achieving UHC [34, 35]. However, this study's analysis revealed that only $10 \%$ of the projects were conducted at the local level, and these projects were mainly ODA projects. For example, the Embassy of Japan in Vietnam allocated their Grant Assistance for Grassroots Human Security Projects for the expansion of five commune health centers in the rural areas of Vietnam. A survey project was also initiated for a need assessment in local areas of rapid diagnosis test kits for hepatitis B virus invented by a Japanese company under the JICA's PPP scheme. Such rapid, affordable, and easy diagnosis tools can be beneficial for securing the health of newborn babies, especially in remote and local areas.

Moreover, various innovative approaches should be proactively initiated so that those providing clinical technical support to health personnel in Vietnamese health facilities can benefit from the improvement of medical services at the local level. Through PPP, several projects at the central hospitals promoted both technical skills transfer of medical services and utilization of Japanese medical devices for efficient medical services. For example, a clinical tele-consultation system between a group of physicians from Vietnam and Japan was developed to improve child cancer diagnosis skills in Vietnam. This kind of telemedicine could be applied to the development of remote clinical consultation systems for rural or hard-to-reach areas in Vietnam.

Simultaneously, community-based health promotion as well as elderly care and support are also imperative to respond to the increasing prevalence of noncommunicable diseases and the needs of an aging society [32]. Vietnam is the one of the most rapidly aging countries in Asia $[36,37]$. Thus, the role of Vietnam's local communities in healthcare is critical as they can take on responsibility for providing comprehensive and easily accessible care and support to the elderly in their communities [38, 39]. In July 2019, the Japanese and Vietnamese governments signed a Memorandum of Cooperation in the field of healthcare [40]. This memorandum emphasized the promotion of a Japanese policy called the Asia Health and Wellbeing Initiative that aims to foster development of long-term care for elderly people through the PPP approach and human resource exchange programs. The Asia Health and Wellbeing Initiative, which is led by the Japanese government, should be taken as an opportunity to boost Japan's development cooperation for community based long-term care and support for the elderly in Vietnam [41].

Ensuring efficient and effective overall development cooperation for health

Despite the fact that Japan devotes a large portion of its public funds to bolster the health scenario in Vietnam, only a small number of projects included in our study reported outcomes with objective indicators. Outcome indicators were likely to be reported if the project period was longer than four years. Instead, only output indicators were reported by projects that culminated within three years where a majority of them were implemented for only one year. A sufficient project period, therefore, is needed to allow for measurement and evaluation, which should focus on the outcomes of cooperation that primarily aims to improve the health of the people [42]. In addition, it is desirable to establish an independent body of external experts for technical guidance on monitoring and evaluation across schemes. 
In this study, numerous projects by Japanese resources were identified that were implemented simultaneously to improve the health sector of Vietnam. However, this study was unable to capture the synergetic effects produced by potential collaboration or harmonization between these projects. Prior to this study, aside from the data on ODA, there were no comprehensive data on Japan's overall health cooperation projects for a recipient country. In this regard, it would be ideal for the Japanese government to set a country-specific mechanism for strategic coordination across the ministries for development cooperation for health. Such a step will not only aid the efficiency of Japan but also promote coordination among other donors and partners in Vietnam [43,44], or any other country. In fact, taking the current study as an opportunity, the Embassy of Japan in Vietnam has begun to release a list of Japanese health cooperation projects in Vietnam [45], by utilizing the project information gathered in this study.

Strengths and limitations of this study

Continuous improvement of objective assessment with internationally common frameworks is required for development cooperation for health. In particular, Japan's cooperation approach is diversifying; therefore, it would be helpful to examine whether the cooperation is relevant to the recipient country's health policy and efforts. There are only a very limited number of studies on Japan's development assistance for health, and these studies have assessed ODA funding at a global level [46]. However, the current study is the first to reveal Japan's unique approach for development cooperation for health at the recipient country level by mobilizing both Japan's ODA and non-ODA public budget.

The six building blocks framework that was utilized in our study refers to the essential functions of health systems. Inter-dependence between blocks is the nature of a well-functioning health system $[9,11]$. This may imply that defining the characteristics of each project with only a single block is unrealistic. Since utilizing this framework simply in analysis has a limitation [24, 25], interaction with other blocks should be considered in understanding the extent to which projects address each of the building blocks. We countered this issue in our study through additional analysis using the recategorized six building blocks, which reflected a more comprehensive understanding of the focus areas of each project. This approach also had a limitation in that we equally redistributed the health administration levels and building blocks as we did not have the relevant information to determine the proportionate variation in the characteristics of these projects according to health administration level and building blocks. In order to elaborate on how projects addressed each building block in their multiple approaches rather than in terms of equal proportions, in-depth interviews with each project implementing organization will be required.

In terms of capturing the overall Japanese resources in development cooperation for health, there were some limitations of this study. First, we had no systematic way of identifying other possible Japanese interventions except for the major Japanese independent administrative agencies in the fields of health and development. Thus, this study did not cover other potential health projects, especially research projects using public funds that worked in collaboration with Vietnamese institutes. Second, the target projects were collected majorly based on publicly available information. However, our independent access to the different characteristics of each agency's website may have biased the collected data. Third, several Japanese funded projects have strived together with Vietnamese counterparts on health focus areas such as infectious diseases and maternal and child health. These specific health focus areas can be captured by using the Organisation for Economic Cooperation and Development methodology [47], which our study did not employ. However, based on the data of the current study, a future study can assess the distribution of Japanese projects by health administration level based on the framework of "capacity building," "infrastructure," "medical equipment," and "research and development" to lend insight into the characteristics of Japan's contribution for development cooperation for health. Last, the results of this study cannot be generalized to Japan's overall development cooperation for health, since this was a cross-sectional study focusing on Japan's cooperation initiatives with only one country.

The analytic approach adopted in this study needs to be developed further to capture a more realistic proportion of each area that the projects worked for. Despite its limitations, the WHO's six building blocks framework can be utilized with such an arrangement to try capturing efforts on health system strengthening. Although the assessment framework for health system strengthening needs improvement, this study was the first to assess Japan's development cooperation for health in a specific recipient country, by including projects funded by both ODA and non-ODA financial resources. In the future, longitudinal studies on Japan's health cooperation with Vietnam are expected. Further external reviews on Japan's development cooperation for health in other recipient countries are also necessary for formulating effective cooperation strategies. An assessment of the mobilization of other Japanese resources from the private sector and private philanthropy is also needed in a future study, considering that these resources are expected to drive health cooperation in the global health architecture [48].

Lastly, donor countries should examine international cooperation to strengthen the health system of the target country as some top ODA donor countries do $[25,42,49]$. Objective and systematical reviews of health cooperation based on internationally common assessment frameworks such as the one used in the current study should be promoted. Consequently, the review results should be reflected in the development of recommendations on the cooperation strategy. Based on the current study's review, priority setting should be strategized and the synergetic effects of various projects employing Japanese resources should be increased to realize efficient and effective development cooperation for health. 


\section{Conclusion}

Health is one of the most prioritized areas in Japan's development cooperation, and the need for health cooperation is increasing globally. With the growing number of project actors within Japan, this research was the first to systematically assess and identify the overall picture of Japan's development cooperation for health in Vietnam by mobilizing both ODA and non-ODA public funds.

A number of Japanese funded projects addressed a wide range of health issues across all six building blocks of the health system in Vietnam. However, there is room for improvement in developing coordination and harmonization among Japanese projects that are diversifying. Moreover, establishing a target country specific mechanism for strategic coordination across Japanese ministries' schemes is expected for efficient and effective development cooperation for health. At a global level, our analytic approach using the recategorized six building blocks would be useful for a more comprehensive understanding of other global health actors' efforts on strengthening the health system.

\section{Abbreviations}

AMED

Japan Agency for Medical Research and Development; DOHA:Direction Office for Healthcare Activities; JICA:Japan International Cooperation Agency; METI:Ministry of Economy, Trade and Industry; MHLW:Ministry of Health, Labour and Welfare; ODA:Official Development Assistance; PHC:Primary health care; PPP:Public-Private Partnership scheme; UHC:Universal health coverage; WHO:World Health Organization

\section{Declarations}

\section{Acknowledgement}

We would like to thank the staff of Japanese governments and agencies who collaborated to provide information on the projects and provided their opinions on the preliminary results. We would also like to thank to Yoko Iwaki for assisting in the collection of project data, and the personnel who assisted in collecting health system information of Vietnam. Eiji Hinoshita is the director of the Ministry of Defense of Japan, but his views do not represent the views of his organization.

\section{Consent for publication}

Not applicable.

\section{Author's contributions}

SL designed the research project and wrote the first draft of manuscript. SL and MU collected data and coded it with the assistance of Al. SL, TT, MKS, Al, and MU analyzed and interpreted the data. All authors made critical revisions to the manuscript and approved the final version of the manuscript.

\section{Availability of data and materials}

All data generated or analyzed during this study are included in this published article and its supplementary information files.

\section{Competing Interests}

The authors declare that they have no competing interests.

\section{Funding}

This study was partly funded by an operational fund of the National Center for Global Health and Medicine. The funders had no role in study design, data collection and analysis, or preparation of the report.

\section{Ethics approval and consent to participate}

Not applicable.

\section{References}

1. United Nations. Resolution adopted by the General Assembly on 10 October 2019: 74/2. Political declaration of the high-level meeting on universal health coverage. New York: United Nations; 2019. https://undocs.org/en/A/RES/74/2. Accessed 1 July 2020. 
2. United Nations. Addis Ababa Action Agenda of the Third International Conference on Financing for Development (Addis Ababa Action Agenda), The final text of the outcome document adopted at the Third Internatinal Conference on Financing for Development (Addis Ababa, Ethiopia, 13-16 July 2015) and endorsed by the General Assembly in its resolution 69/313 of 27 July 2015. New York: United Nations; 2015. https://www.un.org/esa/ffd/wp-content/uploads/2015/08/AAAA_Outcome.pdf. Accessed 10 July 2020

3. OECD. Development Co-operation Profiles. OECD; 2020. https://www.oecd-ilibrary.org/development/development-co-operationprofiles_2dcf1367-en. Accessed 25 July 2020.

4. Ministry of Foreign Affairs. Cabinet decision on the Development Cooperation Charter,. 2015. https://www.mofa.go.jp/mofaj/files/000067701.pdf. Accessed 10 Aug 2017.

5. Ministry of Foreign Affairs. Basic Design for Peace and Health (Global Health Cooperation). Tokyo: Ministry of Foreign Affairs; 2015. https://www.mofa.go.jp/files/000110234.pdf. Accessed 9 July 2018.

6. Headquarters for Healthcare Policy. Healthcare Policy (provisional); Approved by Cabinet July 22, 2014, Partially Revised February 17, 2017. Headquarters for Healthcare Policy; 2017. https://www.kantei.go.jp/jp/singi/kenkouiryou/en/pdf/2017_policy.pdf. Accessed 1 May 2018.

7. Ministry of Foreign Affairs. White Paper on Development Cooperation 2018: Japan's international cooperation Tokyo: Ministry of Foreign Affairs; 2020. https://www.mofa.go.jp/files/000554934.pdf. Accessed 25 July 2020.

8. Organisation for Economic Co-operation and Development. Aid (ODA) disbursements to countries and regions. . Organisation for Economic Co-operation and Development,; 2020. https://stats.oecd.org/viewhtml.aspx?datasetcode=TABLE2A\&lang=en\#. Accessed 1 August 2020

9. World Health Organization. Everybody's business: strengthening health systems to improve health outcomes: WHO's framework for action. . Geneva: World Health Organization; 2007. https://www.who.int/healthsystems/strategy/everybodys_business.pdf. Accessed 10 August 2017.

10. World Health Organization. Monitoring the building blocks of health systems: a handbook of indicators and their measurement strategies. Geneva. : World Health Organization; 2010. https://www.who.int/healthsystems/strategy/everybodys_business.pdf?ua=1. Accessed 10 Aug 2017.

11. World Health Organization Maximizing Positive Synergies Collaborative Group, Samb B, Evans T, Dybul M, Atun R, Moatti JP, et al. An assessment of interactions between global health initiatives and country health systems. Lancet (London, England). 2009;373(9681):213769.

12. Shakarishvili G AR, Berman P, Hsiao W, Burgess C, Lansang MA,. Converging health systems frameworks: towards a concepts-to-actions roadmap for health systems strengthening in low and middle income countries. Global Health Governance. 2010;3.

13. Biesma RG, Brugha R, Harmer A, Walsh A, Spicer N, Walt G. The effects of global health initiatives on country health systems: a review of the evidence from HIV/AIDS control. Health Policy Plan. 2009;24(4):239-52.

14. Bryce J, Requejo JH, Moulton LH, Ram M, Black RE. A common evaluation framework for the African Health Initiative. BMC health services research. 2013;13 Suppl 2(Suppl 2):S10.

15. World Health Organization. Service Availability Readiness Assessment (SARA): an annual monitoring system for service delivery. Reference manual Ver 2.2. Geneva, Switzerland. : World Health Organization; 2015.

https://www.who.int/healthinfo/systems/sara_reference_manual/en/. Accessed 1 March 2018.

16. Tello J. and Barbazza E. Health service delivery: a concept note. WEURO Working Document. . World Health Organization regional office for Europe; 2015. https://www.euro.who.int/_data/assets/pdf_file/0020/291611/Health-Services-Delivery-A-concept-note-301015.pdf?ua=1. Accessed 1 March 2018.

17. de Savigny D, Adam T, editors. Systems Thinking for Health Systems Strengthening. Alliance for Health Policy and Systems Research. Geneva: WHO; 2009.

https://apps.who.int/iris/bitstream/handle/10665/44204/9789241563895_eng.pdf;jsessionid=0EA4B03900E299EE59DAC2ABCB782405? sequence=1. Accessed 15 July, 2020.

18. Warren AE, Wyss K, Shakarishvili G, Atun R, de Savigny D. Global health initiative investments and health systems strengthening: a content analysis of global fund investments. Globalization and health. 2013;9(1):30.

19. ODA Evaluation Division, Minister's Secretariat, Ministry of Foreign Affairs of Japan. ODA Evaluation Guidelines, 12th Edition. Tokyo: Ministry of Foreign Affairs of Japan; 2019. https://www.mofa.go.jp/policy/oda/evaluation/basic_documents/pdfs/guidelines12th.pdf. Accessed 10 May 2020.

20. Organisation for Economic Co-operation and Development. Glossary of Key Terms in Evaluation and Results Based Management. Paris: Organisation for Economic Co-operation and Development; 2010. http://www.oecd.org/development/peer-reviews/2754804.pdf Accessed 10 Mar 2020. 
21. Ministry of Foreign Affairs of Japan. Annual Report on Japan's ODA Evaluation 2016 Tokyo: Ministry of Foreign Affairs of Japan; 2016. https://www.mofa.go.jp/policy/oda/evaluation/annual_report_2016/index.html. Accessed 10 December 2017.

22. World Health Organization. Regioal Office for the Western Pacific. Human resources for health country profiles: Viet Nam. World Health Organization; 2016. https://iris.wpro.who.int/handle/10665.1/13476. Accessed 24 July 2020.

23. Takashima K, Wada K, Tra TT, Smith DR. A review of Vietnam's healthcare reform through the Direction of Healthcare Activities (DOHA). Environ Health Prev Med. 2017;22(1):74.

24. Sherr K, Fernandes Q, Kante AM, Bawah A, Condo J, Mutale W, et al. Measuring health systems strength and its impact: experiences from the African Health Initiative. BMC health services research. 2017;17(Suppl 3):827.

25. Munir K, Worm I. Health systems strengthening in German development cooperation: making the case for a comprehensive strategy. Globalization and health. 2016;12(1):81.

26. Dieleman JL, Sadat N, Chang AY, Fullman N, Abbafati C, Acharya P, et al. Trends in future health financing and coverage: future health spending and universal health coverage in 188 countries, 2016-40. The Lancet. 2018;391(10132):1783-98.

27. World Health Organization. Key components of a well functioning health system. Geneva: 2010. https://www.who.int/healthsystems/EN_HSSkeycomponents.pdf?ua=1. Accessed 11 July 2020.

28. Japan International Cooperation Agency Vietnam Office. JICA Vietnam: Inclusive and Dynamic Development. JICA Vietnam Office. 2012. https://www.jica.go.jp/vietnam/office/others/pamphlet/pamphlet.html. Accessed 20 July 2020.

29. Ministry of Heath Vietnam. PLAN For people's health protection, care and promotion 2016-2020. Hanoi: 2016. http://hpg.icdmoh.gov.vn/upload_images/files/Five-year\%20Health\%20Plan\%202016-20\%20(EN).pdf. Accessed 1 March 2018.

30. Oanh TTM TK, Phuong H, Phuong NK, Due OT, Hort K. Public hospital governance in Viet Nam: acase study in two provinces. In: Public Hospital Governance in Asia and the Pacific, edited by Huntington D and Hort K. pp. 98-136. . Geneva: World Health Organization; 2015. http://www.wpro.who.int/asia_pacific_observatory/country_comparative_studies/ccs_public_hospital_4_vnm.pdf?ua=1. Accessed 10 July 2020.

31. Huy NV, Hieu TT, Mai NT, Thang NH, Nga TT, Nam NDH, et al. Human Resources for Commune Health Centers as per National Standards: The Case of Vietnam. Fam Med Med Sci Res. 2019;8(1 No:236).

32. World Health Organization. VIET NAM; Improving equity in access to primary care, country case studies on primary health care. WHO; 2018. https://apps.who.int/iris/bitstream/handle/10665/326257/WHO-HIS-SDS-2018.36-eng.pdf. Accessed 1 July 2020.

33. Van Huy N, Nam YS, Van Thanh N, Tuan NT, Ha NTT, Hoat LN, et al. WHO's Service Availability and Readiness Assessment of primary health care services of commune health centers in a rural district of Northern Vietnam. Int J Health Plann Manage. 2018;33(1):202-11.

34. World Health Organization and the United Nations Children's Fund (UNICEF). Declaration of Astana; Astana Kazakhstan 25-26 October 2018, Global Conference on Primary Health Care. World Health Organization and the United Nations Children's Fund (UNICEF); 2018. https://www.who.int/docs/default-source/primary-health/declaration/gcphc-declaration.pdf. Accessed 1 July 2020.

35. World Health Organization. Primary Health Care on the Road to Universal Health Coverage; 2019 Global Monitoring Report, conference edition,. 2018. https://www.who.int/healthinfo/universal_health_coverage/report/uhc_report_2019.pdf. Accessed 1 July 2020.

36. General Statistics Office and United Nations Population Fund. Vietnam Population Projection 2014-2049. Hanoi: Vietnam News Agency Publishing House; 2016. https://vietnam.unfpa.org/sites/default/files/pubpdf/PD_English_Monograph_Viet\%20Nam\%20Population\%20projection_2016.pdf. Accessed 10 August 2020.

37. Vietnam National Committtee on Ageing and United Nations Population Fund. Towards a comprehensive national policy for an ageing Viet Nam. Ha Noi: Vietnam National Committtee on Ageing; 2019. https://vietnam.unfpa.org/sites/default/files/pubpdf/Toward\%20a\%20comprehensive\%20ageing\%20policy_ENG.pdf. Accessed 11 August 2020.

38. World Health Organization Regional Offce for the Western Pacific. Regional framework for action on ageing and health in the Western Pacific (2014-2019). WHO; 2014. https://www.who.int/vietnam/health-topics/ageing-and-health/publications. Accessed 25 July 2020.

39. World Health Organization. Ageing and health: Ageing and health in Viet Nam. WHO Representative Office for Viet Nam; 2020. https://www.who.int/vietnam/health-topics/ageing-and-health. Accessed 25 July 2020.

40. The Cabinet Secretariat of Japan. Signinig of the memorandum of cooperation in the health sector of Vietnam. The Cabinet Secretariat of Japan; 2019. https://www.kantei.go.jp/jp/singi/kenkouiryou/pdf/20190701_vietnam_hc.pdf. Accessed 29 July 2020.

41. The Asia Health and Wellbeing Initiative (AHWIN). About AHWIN. Economic Research Institute for ASEAN and East Asia (ERIA) and Japan Center for International Exchange (JCIE); 2020. https://www.ahwin.org/about-ahwin/. Accessed 20 July 2020.

42. IOM (Instititue of Medicine). Investing in Global Health Systems: Sustaining Gains, Transforming Lives. Washington, D.C.: The National Academies Press; 2014. http://www.ressma.com/Documentation/BIBLIO/GOUVERNANCE/NAP_Investing_Global-Health-Systems.pdf. Accessed 11 July 2020. 
43. EU-Luxembourg-WHO UHC Partnership. Year 6 Report (2017 activities), Country:Viet Nam. Universal Health Coverage Partnership; 2017. https://www.uhcpartnership.net/country-profile/vietnam/. Accessed 2 May 2020.

44. Health partnership group Viet Nam. About; Goal \& commitments (what we aim to). 2020. http://hpg.icdmoh.gov.vn/about-ce11.html. Accessed 1 August 2020.

45. The Embassy of Japan in Vietnam. Japan-Vietnam cooperation in the health sector [Japanese]. The Embassy of Japan in Vietnam; 2020. https://www.vn.emb-japan.go.jp/itpr_ja/iryobunya_nichietsukyoryoku.html. Accessed 1 July 2020.

46. Nomura S, Sakamoto H, Sugai MK, Nakamura H, Maruyama-Sakurai K, Lee S, et al. Tracking Japan's development assistance for health, 2012-2016. Globalization and health. 2020;16(1):32.

47. Organisation for Economic Co-operation and Development. DAC and CRS code lists. Paris: Organisation for Economic Cooperation and Development. http://www.oecd.org/development/financing-sustainable-development/development-financestandards/dacandcrscodelists.htm. Accessed 1 July 2019.

48. Dieleman JL, Schneider MT, Haakenstad A, Singh L, Sadat N, Birger M, et al. Development assistance for health: past trends, associations, and the future of international financial flows for health. The Lancet. 2016;387(10037):2536-44.

49. International Development Committee. Strengthening Health Systems in Developing Countries. Fifth Report of Session 2014-15. London,: IDC; 2014. Available from: https://publications.parliament.uk/pa/cm201415/cmselect/cmintdev/246/24602.htm.

\section{Figures}

\begin{tabular}{|c|c|}
\hline $\begin{array}{l}\text { Projects identified through } \\
\text { internet search } \\
\text { (81) }\end{array}$ & \\
\hline & $\begin{array}{l}\text { Projects not funded by public funds as of } \\
\text { December } 2016 \\
\text { ( } 2 \text { excluded) }\end{array}$ \\
\hline & $\begin{array}{l}\text { Projects that were a part of a larger research project } \\
\qquad \text { ( } 7 \text { excluded) }\end{array}$ \\
\hline $\begin{array}{l}\text { Projects screened } \\
\qquad(72)\end{array}$ & \\
\hline & $\begin{array}{l}\text { Project whose primary purpose did not serve to } \\
\text { improve the health system of vietnam } \\
\text { ( } 1 \text { excluded })\end{array}$ \\
\hline & $\begin{array}{l}\text { Projects whose counterparts were not disclosed } \\
\qquad \text { (2 excluded) }\end{array}$ \\
\hline $\begin{array}{l}\text { Final Target Projects } \\
\text { included for analysis }\end{array}$ & $\begin{array}{l}\text { Duplicate of projects } \\
\text { (1 excluded) }\end{array}$ \\
\hline
\end{tabular}

Figure 1

Selection process of the target projects 


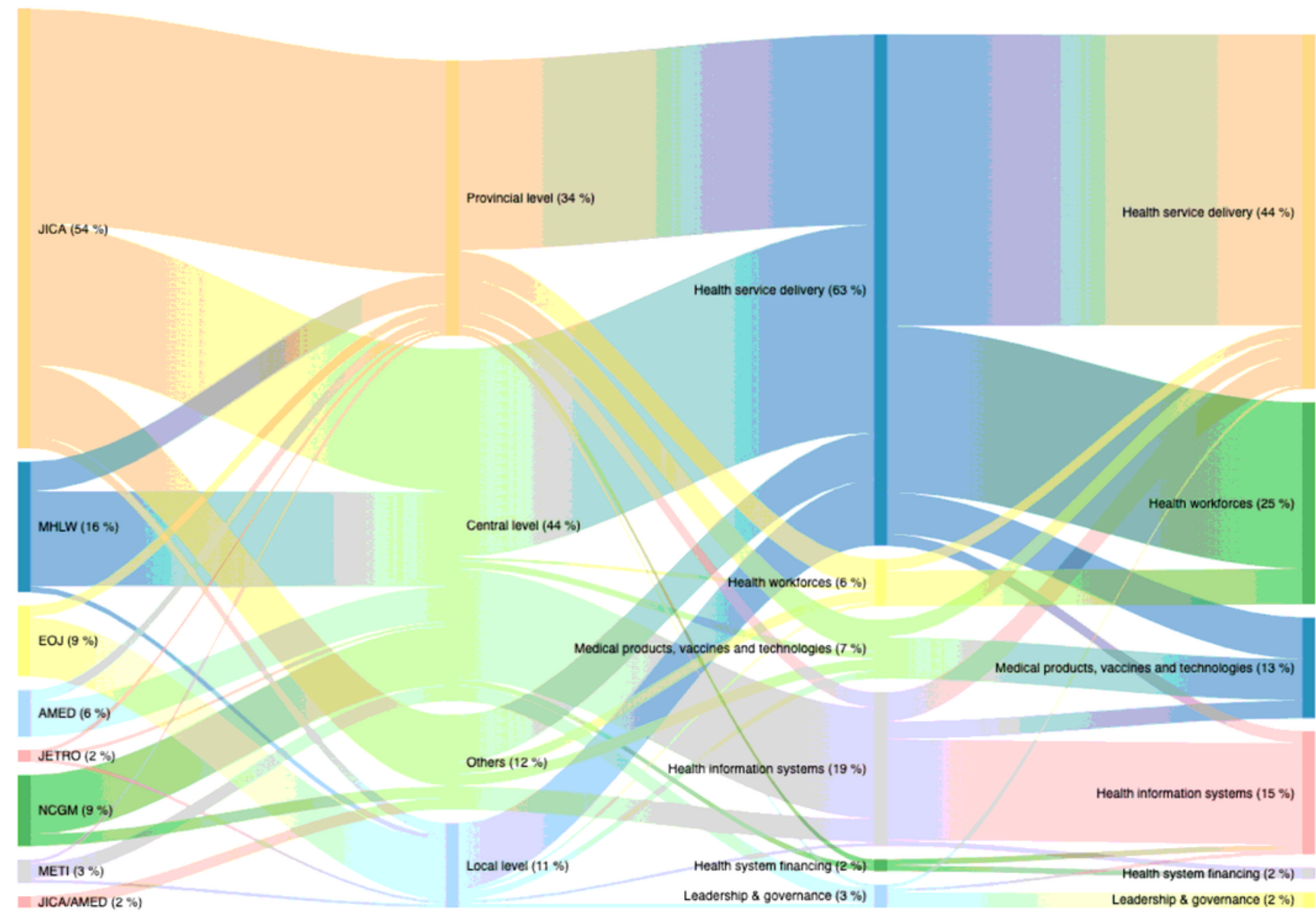

\section{Figure 2}

Flow of proportions of the number of projects implemented by Japanese public funds to Vietnam, by source, health administration level, and purposes categorized into the World Health Organization's six building blocks (the main category and recategorized building blocks) JICA Japan International Cooperation Agency (JICA); MHLW Ministry of Health, Labour and Welfare; EOJ Embassy of Japan in Vietnam; AMED Japan Agency for Medical Research and Development; JETRO Japan External Trade Organization; NCGM the National Center for Global Health and Medicine; METI Ministry of Economy, Trade, and Industry; Note: the proportions were estimated by using a total number of projects (68 projects) that were identified from publicly available resources as the denominator. 


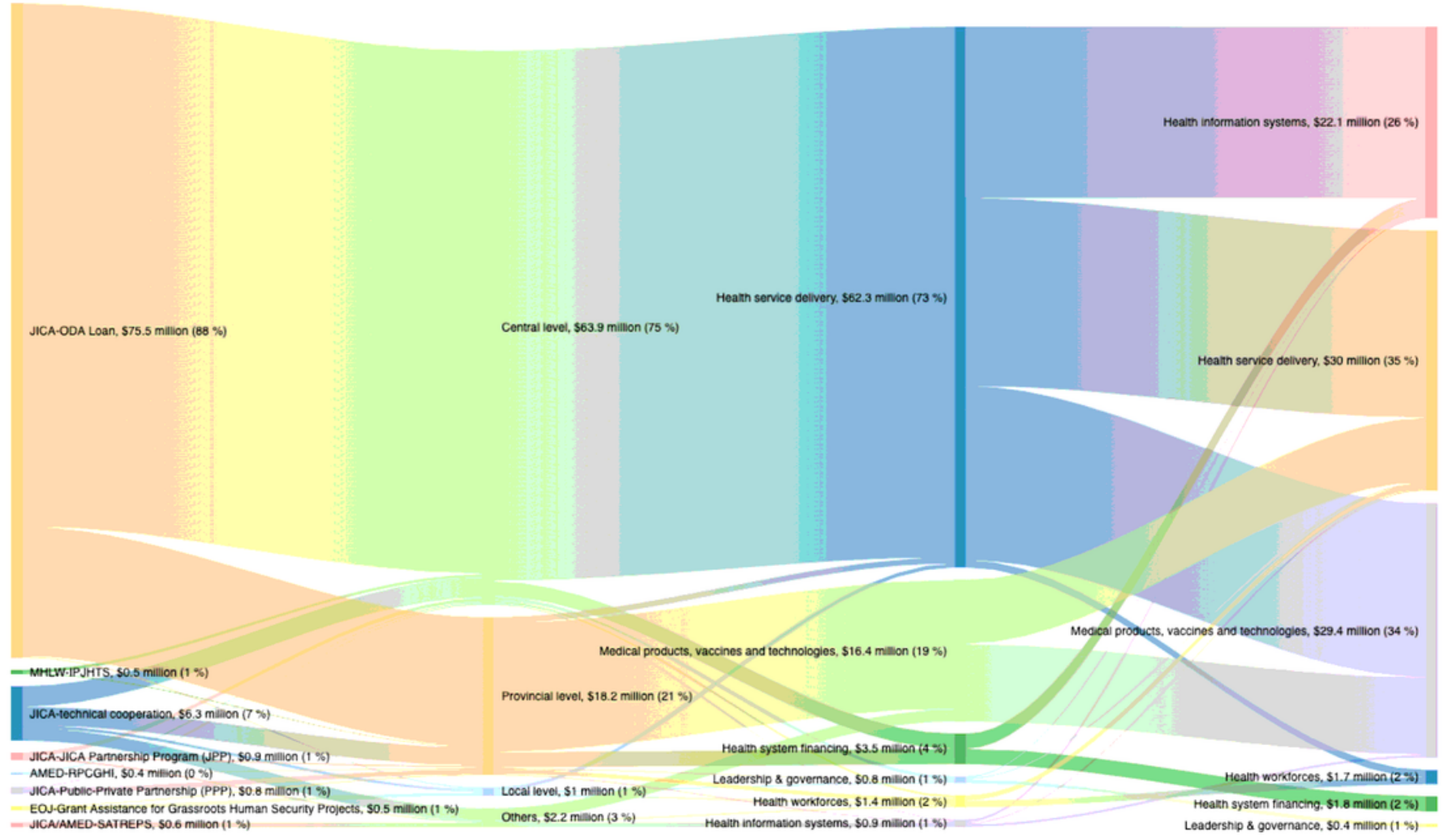

\section{Figure 3}

Flow of annual project budgets from both Japan's ODA and non-ODA public funds that were implemented for health projects in Vietnam in 2016, by scheme operating organizations and their scheme types, health administration level, and purposes categorized into WHO's six building blocks (the main category and recategorized building blocks) (2016 USD) JICA Japan International Cooperation Agency; MHLW Ministry of Health, Labour, and Welfare; IPJHTS The International Promotion of Japan's Healthcare Technologies and Services; PPP Public-Private Partnership; EOJ Embassy of Japan in Vietnam; AMED Japan Agency for Medical Research and Development; SATREPS Science and Technology Research Partner-ship for Sustainable Development. Note: IPJHTS is an unofficial abbreviation created only for the purpose of this paper. The proportions were estimated with a total budget of resource allocation that were identified from publicly available resources (39 projects) as the denominator 

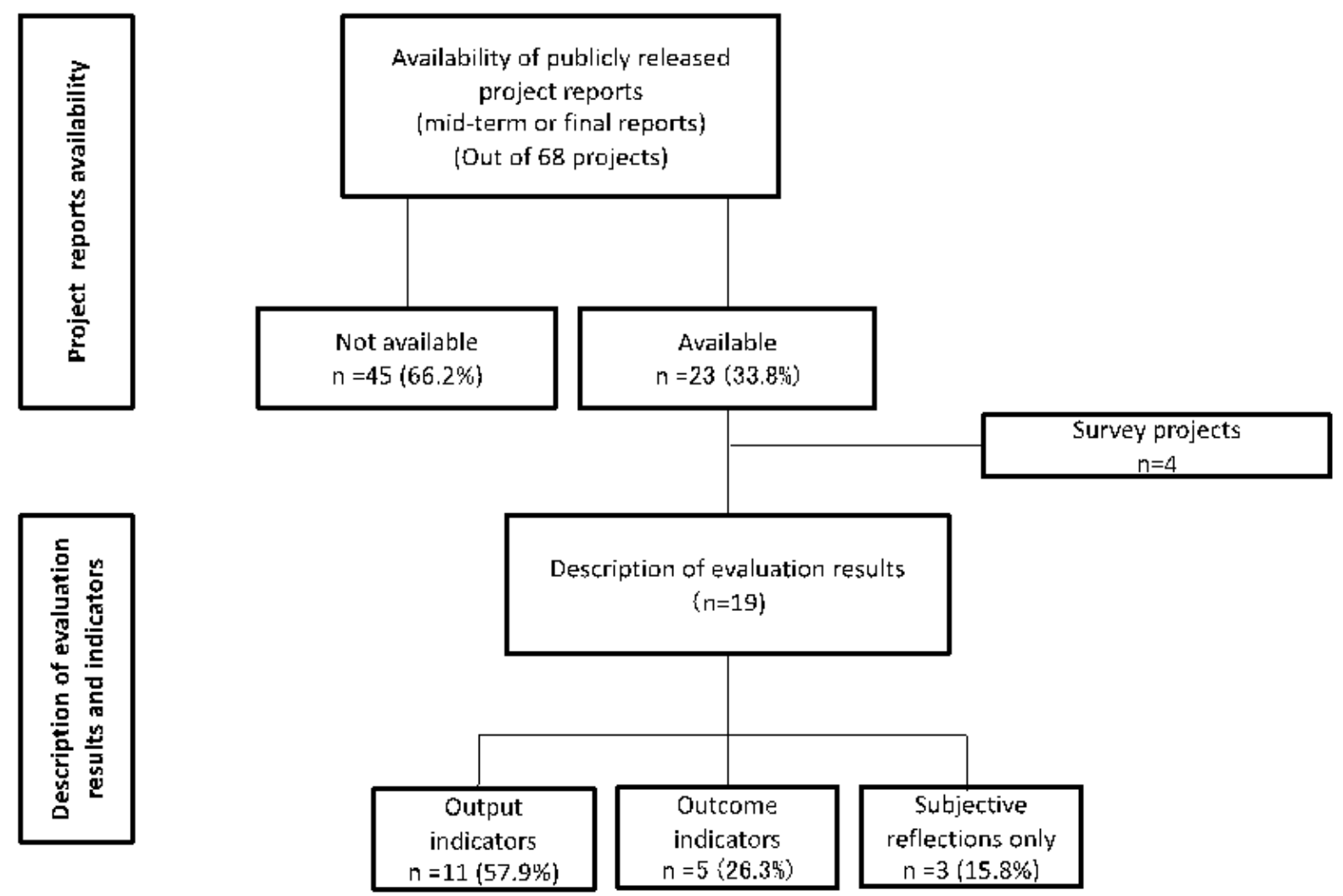

Figure 4

Assessment of reporting project evaluation with the project outcome indicators

\section{Supplementary Files}

This is a list of supplementary files associated with this preprint. Click to download.

- Additionalfile2.xlsx

- Additionalfile1.xlsx 